\title{
PERANAN GURU BIMBINGAN KONSELING DALAM MENGEMBANGKAN KEPRIBADIAN SISWA
}

\author{
Aep Saepuloh \\ STIT Buntet Pesantren Cirebon \\ aepsaepuloh300@gmail.com
}

\begin{abstract}
This study aims to analyze the guidance and counseling teacher in developing the personality of class $X$ students of SMK President of Cirebon. To find out the personality of students, the writer is interested in researching about the BK teacher in developing the personality of students in SMK President of Cirebon. Respondents in this study were President SMK students. From the population of class $X$ students of SMK President Cirebon City, 85 students were sampled 25\% of the population, namely 22 students. The method used in this research is descriptive quantitative method. Data obtained through literature review as theoretical and empirical data through studies using observations, questionnaires, and documentation studies. Data analysis shows the average value of the results of the guidance and counseling questionnaire is 90.64 or $90 \%$ with the category of Strong, while the average value of student personality results is 90.64. This shows the effectiveness of development in class X SMK President Cirebon City is high. The relationship between guidance and counseling and student personality shows a strong category with a score of 90.09. The result of $T$ is 0.009 which means that it is significant between the guidance and counseling variable and the student's personality variable because it is smaller than 0.05.
\end{abstract}

Keywords: The Role of Guidance and Counseling Teachers, Personality Development

\begin{abstract}
Abstrak
Penelitian ini bertujuan untuk menganalisis Guru bimbingan dan Konseling dalam Mengembangkan Kepribadian Siswa Kelas X SMK Presiden Kota Cirebon. Untuk mengetahui Kepribadian Siswa maka penulis tertarik untuk meneliti tentang Guru BK dalam mengembangkan kepribadian siswa di SMK Presiden Kota Cirebon. Responden dalam penelitian ini adalah siswa SMK Presiden. Dari populasi siswa kelas X SMK Presiden Kota Cirebon sejumlah 85 siswa sampel $25 \%$ dari jumlah populasi yaitu 22 siswa. Metode yang digunakan dalam penelitian ini adalah metode kuantitatif bersifat deskriptif. Data diperoleh melalui kajian pustaka sebagai teoritisnya dan data empiris melalui studi dengan menggunakan observasi, angket, dan studi dokumentasi. Analisis data menunjukkan nilai rata-rata hasil angket bimbingan dan konseling yaitu 90,64 atau $90 \%$ dengan kategori Kuat, sedangkan nilai rata-rata hasil kepribadian siswa yaitu 90,64. Hal tersebut menunjukkan efektifitas pengembangan pada siswa kelas X SMK Presiden Kota Cirebon termasuk tinggi. Hubungan antara bimbingan dan konseling dan kepribadian siswa menunjukan kategori kuat dengan skor 90,09. Hasil T adalah 0,009 yang bearti signifikan antara variabel bimbingan dan konseling dan variabel kepribadian siswa karena lebih kecil dari 0,05.
\end{abstract}

Keywords: Peranan Guru Bimbingan dan Konseling, Pengembangan Kepribadian

\section{Pendahuluan}

Nilai bimbingan yang terdapat dalam ajaran Al-Qur'an dapat digunakan pembimbing untuk membantu si terbimbing dalam menentukan pilihan perubahan tingkah laku positif. Diantara dasar-dasar 
bimbingan dan konseling dalam al-Qurean antara lain:

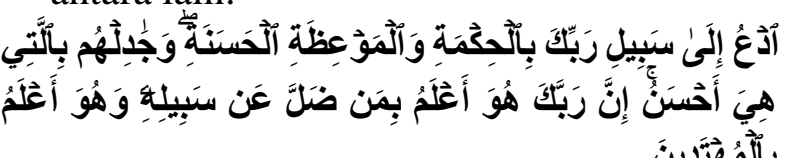

"Serulah (manusia) kepada jalan Tuhan-mu dengan hikmah dan pelajaran yang baik dan bantahlah mereka dengan cara yang baik. Sesungguhnya Tuhanmu Dialah yang lebih mengetahui tentang siapa yang tersesat dari jalan-Nya dan Dialah yang lebih mengetahui orang-orang yang mendapat petunjuk" (QS. An-Nahl/16: 125).

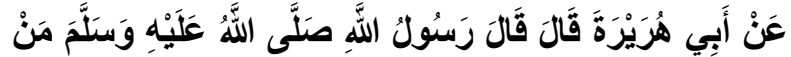

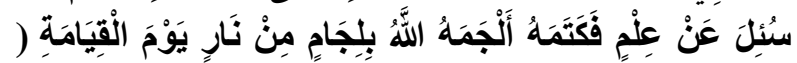

رواه أبو داود) - إن

"Dari Abu Hurairah berkata, Rasulululah SAW bersabda: Barang siapa ditanya tentang suatu ilmu, lalu dirahasiakannya, maka dia akan datang pada hari kiamat dengan kendali (di mulutnya) dari api neraka" (HR. Abu Daud)

Bimbingan adalah proses pemberian bantuan kepada individu yang dilakukan secara berkesinambungan supaya individuindividu tersebut dapat memahami dirinya sehingga sanggup mengarahkan diri dan dapat bertindak wajar sesuai dengan tuntutan dan keadaan keluarga serta masyarakat. Definisi bimbingan dikemukakan dalam Year's Book of Education ( 1995: 102 ) menyatakan bahwa"guidance is a process of helping individual through their own effort to discover develop their potentialisties both for personal happines sosial usefulness". Definisi tersebut menjelaskan bahwa:"Bimbingan adalah proses bantuanterhadap individu untuk mencapai melalui pemahaman diri dan pengarahan diri yang dibutuhkan untuk melakukan penyesuaian diri secara maksimum kepada sekolah, keluarga, serta masyarakat. Rochman Natawidjaja dalam bukunya Syamsu Yusuf (2005:6) Bimbingan dapat diartikan sebagai suatu proses pemberian bantuan kepada individu yang dilakukan secara berkesinambungan supaya individu tersebut dapat memahami dirinya sendiri, sehingga dia sanggup dengan tuntutan dan keadaan lingkungan sekolah. Pryitno dan Erman Amti (2013 : 99) mengemukakan bahwa bimbingan adalah proses pemberian bantuan yang dilakukan oleh orang yang ahli kepada seseorang individu, baik anak-anak, remaja maupun dewasa agar orang yang dibimbing dapat mengembangkan kemampuan dirinya sendiri dan mandiri dengan memanfaatkan kekuatan individu dan sarana yang ada dan di kembangkan berdasarka norma-norma yang berlaku.

Winkel dalam bukunya Sutirna (2013:11), mendefenisikan bimbingan: (1) suatu usaha untuk melengkapi individu dengan pengetahuan, pengalaman dan informasi tentang dirinya sendiri, (2) suatu cara untuk memberikan bantuan kepada individu untuk memahami dan mempergunakan secara efisien dan efektif segala kesempatan yang dimiliki untuk perkembangan pribadinya, (3) sejenis pelayanan kepada individu-individu agar mereka dapat menentukan pilihan (4) suatu proses pemberian bantuan atau pertolongan kepada individu dalam hal memahami diri sendiri dan tuntutan lingkungan.

Selanjutnya Bimo Walgito (2010:6) menegaskan bahwa dalam duni pendidikan bantuan yng dikatakan bimbingan adalah seperti yang dikatakan Kihajar Dewantara, yaitu seyogyanya "Tut Wuri Handayani"(ketika berada dibelakang kita harus mendorong anak-anak atau mengarahkan anak-anak untuk maju).

Dari pengertian bimbingan yang dikemukakan oleh para ahli diatas,maka penulis dapat menyimpulkan bahwa bimbingan merupakan : 
a. Suatu pertolongan yang menuntun, Bimbingan merupakan suatu tuntutan, hal ini mengandung pengertian bahwa dalam memberikan bimbingan bila keadaan menuntut, kewajiban dari pembimbing untuk memberikan bimbingan secara aktif, yaitu memberikan arahan kepada yang dibimbingnya.

b. Bantuan yang diberikan itu dimaksudkan agar individu-individu yang bersangkutan dapat mengarahkan dan mengembangkan dirinya secara optimal sesuai kemampuan dan potensinya.

c. Kegiatan yang bertujuan utama memberikan bantuan agar individu dapat memahami keadaan dirinya dan mampu menyesuaikan dengan lingkunganya.

Secara etimologis, istilah konseling berasala dari bahasa Latin, yaitu "consilium" yang berarti "dengan" atau "bersama" yang dirangkai dengan "menerima" atau "memahami". Sedangkan dalam bahasa Anglo-Saxon, istilah konseling berasal dari "sellan" yang berarti "menyerahkan" atau "menyampaikan".Konseling adalah hubungan pribadi yang dilakukan secara tatap muka antara dua orang dalam mana konselor melalui hubungan itu dengan kemampuan-kemampuan khusus yang dimilikinya, menyediakan situasi belajar. Jones (dalam Bimo Walgito, 2010:7) menyampaikan bahwa pengertian konseling sebagai berikut: "Counseling is talking over a problem with some one.Usually but not always, one of the two has facts or experience or abilities not possesed to the same degree by the other. The process of counseling involves a clearing up of the problem by discussion. Jones mengatakan bahwa konseling itu membicarakan masalah seseorang dengan berdiskusi dalam prosesnya, hal ini dapat dilakukakan secara individual atau kelompok, jika dilakukan secara individual dimana masalahnya sangat rahasia dan kelompok masalahnya yang umum (bukan rahasia). Wrenn (dalam Bimo Walgito, 2010:7) mengemukakan bahwa pengertian konseling (terjemahan) adalah : Hubungan pribadi dan dinamis antara dua orang yang bermasalah dengan tujuan agar diketahui permasalahanya sehingga ditemukan solusinya. Shertzer dan Stone (dalam Syamsu Yusuf dan Juntika 2010:6) menyampaikan pengertian konseling adalah "Counseling is an interaction process which facilitates meaningful understanding of self and environment snd result in the establishment or clarification of goals and values of future behavior". Pengertian diatas memiliki arti yang sangat sederhana di mana dikatakan bahwa konseling itu merupakan proses interaksi dalam rangka memberikan pengertian diri dan lingkungannya dan dampaknya atau akibatnya membentuk tujuan dan prilaku untuk masa depannya.

Prayitno dan Erman Amti dikutip dalam buku Sutirna (2013:15) pengertian konseling adalah proses pemberian bantuan yang dilakukakan melalui wawancara konseling seorang ahli (disebut konselor) kepada individu yang sedang mengalami sesuatu masalah (disebut klien) yang bermuara pada teratasinya masalah yang dihadapi klien.

Berdasarkan Dari pengertian konseling yang di kemukakan oleh para ahli di atas, maka penulis dapat menyimpulkan bahwa konseling merupakan:

a. Proses pemberian bantuan yang dilakukan melalui wawancara Konseling oleh seorang ahli (disebut Konselor) kepada individu yang sedang mengalami masalah (disebut klien) yang bermuara pada teratasinya masalah yang dialami oleh klien.

b. Konseling adalah usaha membantu konseli atau klien secara tatap muka dengan tujuan agar klien dapat mengambil tanggung jawab sendiri terhadap berbagai persoalan atau masalah khusus. Dengan kata lain, 
teratasinya masalah yang dihadapi oleh konseli atau klien.

c. Konseling merupakan suatu proses bantuan secara profesional antara konselor dan klien yang bertujuan membantu individu (klien) dalam memecahkan masalahnya agar individu dapat menyesuaikan diri dengan lingkungannya sesuai potensi atau kemampuan yang ada pada dirinya.

\section{Peran Guru Bimbingan dan Konseling di Sekolah}

Dalam kelangsungan perkembangan dan pertumbuhan anak didik, berbagai pelayanan di selenggarakan. Masingmasing pelayanan itu memiliki peran yang sangat berguna dan bermanfaat untuk memperlancar dan memberikan be positive dalam proses perkembangan anak didik, khususnya dalam bidang tertentu yang menjadi fokus pelayanan yang dimaksud. Dengan adanya pelayanan bimbingan konseling, siswa dapat memperoleh keuntungan. Kegunaan, manfaat, keuntungan, atau jasa yang diperoleh dari adanya suatu pelayanan merupakan hasil dari terlaksananya fungsi pelayanan tersebut. Dengan demikian peran bimbingan konseling dapat diketahuai dengan melihat fungsi-fungsi, Tujuan dan Manfaat pelayanan bimbingan konseling seperti yang ada di bawah ini:

\section{a. Fungsi Layanan Bimbingan dan Konseling}

Pelayanan bimbingan dan konseling yang akan diberikan kepada peserta didik berdasarkan fungsinya masing-masing. Sejalan dengan itu, Uman Suherman (dalam Achmad Juntika Nurihsan 2008) menyatakan bahwa secara umum, fungsi bimbingan dan konseling dapat diuraikan sebagai berikut :a.)Fungsi Pemahamanb). Fungsi Reventif c). Fungsi Pengembangan d).Fungsi Penyembuhan e). Fungsi
Penyaluran Pribadi f).Fungsi Adaptasi g). Fungsi Penyesuaian h). Fungsi Perbaikan.

\section{b. Tujuan Bimbingan dan Konseling}

Secara khusus bimbingan dan konseling bertujuan untuk membantu konseli agar dapat mencapai tugas-tugas perkembangannya yang meliputi aspek pribadi-sosial, belajar (akademik), dan kepribadian (Dikutip dalam Buku Sutirna).

1) Tujuan bimbingan dan konseling yang terkait dengan aspek pribadi sosial konseli adalah:

a) Memiliki komitmen yang kuat dalam mengamalkan nilai-nilai keimanan dan ketaqwaan kepada Tuhan Yang Maha Esa, baik dalam kehidupan pribadi, keluarga, maupun masyarakat pada umumnya.

b) Memiliki sikap toleransi terhadap umat beragama lain, dengan saling menghormati dan memelihara hak dan kewajibannya masing-masing.

c) Memiliki pemahaman tentang irama kehidupan yang bersifat fluktuatif antara yang menyenangkan (anugrah) dengan ajaran agama yang dianut.

\section{c. Manfaat Bimbingan dan Konseling}

1) Bimbingan konseling akan membuat diri kita merasa lebih baik, merasa bahagia, tenang dan nyaman karena bimbingan konseling tersebut membantu kita untuk menerima setiap sisi yang ada di dalam diri kita.

2) Bimbingan konseling juga membantu menurunkan bahkan menghilangkan stressdan depresi yang kita alami karena kita dibantu untuk mencari sumber stress tersebut serta dibantu pula mencari cara penyelesaian terbaik dari permasalahan yang belum terselesaikan itu.

3) Bimbingan konseling membantu kita untuk dapat memahami dan 
menerima diri sendiri dan orang lain sehingga akan meningkatkan hubungan yang efektif dengan orang lain serta dapat bedamai dengan diri sendiri.

4) Perkembangan personal akan meningkatkan secara positif karena adanya bimbingan konseling.

Terkait kepribadian manusia, AlQu'an memandang manusia sebagai makhluk Allah SWT yang memiliki keunikan tertentu. Manusia diciptakan dengan bentuk raga yang sebaik-baiknya ( $Q$ S : $95: 4$ ), serta dilengkapi dengan organ psikofisik yang istimewa. Dalam beberapa ayat berikut Al-Quran secara gamblang menegaskan manusia memiliki potensipotensi psikofikk; kekuatan fisik, nafs, akal, hati dan ruh

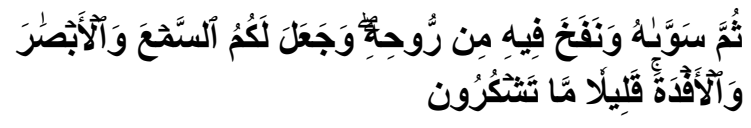

"Kemudian Dia menyempurnakan dan meniupkan ke dalamnya roh (ciptaan)-Nya dan Dia menjadikan bagi kamu pendengaran, penglihatan dan hati; (tetapi) kamu sedikit sekali bersyukur" ( As-Sajdah :9)

Kata kepribadian (Personality) sesungguhnya berasal dari bahasa latin: persona (Akyas Azhari, 2004:161) kata persona merujuk pada topeng yang biasa digunakan para pemain sandiwara di Zaman Romawi. Pada dasarnya definisi dari kepribadian secara umum ini adalah lemah karena hanya menilai perilaku yang dapat diamati saja dan tidak mengabaikan kemungkinan bahwa ciri-ciri ini bisa berubah tergantung pada situasi bagaimanapun pada dasarnya kepribadian itu tidak dapat dinilai "baik" atau "buruk" karena bersifat netral. Lambat laun, kata personal atau personality berubah menjadi istilah yang mengacuh pada gambaran sosial tertentu yang diterima oleh individu dari kelompok atau masyarakatnya, kemudian individu tersebut di harapkan bertingkah laku berdasarkan atau sesuai dengan gambaran sosial (peran) yang di terimanya. (Baharuddin, 2007: 21) sedangkan kata siswa disamakan dengan anak didik, merupakan sekelompok individu yang melakukan kegiatan untuk mencari suatu hal yang belum di mengerti. Dalam proses ini di sebut juga proses belajar mengajar. (Muhammad Alim, 2006: 18).

Menurut teori psikoanalitik Sigmund Freud (1955; 121), dikutip dalam buku (Sumandi Suryabrata 2011) kepribadian terdiri dari tiga elemen. Ketiga unsure kepribadian itu dikenal sebagai Id, Ego, dan Superego, yang bekerjasama untuk menciptakan perilaku manusia yang komplek.

a. Id adalah satu-satunya komponen kepribadian yang hadir sejak lahir atau sistem dasar kepribadian. Menurut Freud, id adalah sumber segala energi psikis, sehingga komponen utama kepribadian. Id didorong oleh prinsip kesenangan. Menurut Freud, id mencoba untuk menyelesaikan ketegangan yang diciptakan oleh prinsip kesenangan melalui proses utama, yang melibatkan pembentukan citra mental dari objek yang diinginkan sebagai cara untuk memuaskan kebutuhan (Di kutip dalam Sumandi.2011:121).

b. Ego adalah struktur kepribadian yang berurusan dengan tuntutan realita, berisi penalaran dan pemahaman yang tepat. Ego berusaha menahan tindakan sampai dia memiliki kesempatan untuk memahami realitas secara akurat, memahami apa yang sudah terjadi di dalam situasi yang berupa dimasa lalu, 
dan membuat rencana yang realistic dimasa depan. Tujuan ego adalah menemukan cara yang realistis dalam rangka memuaskan Id.

c. Super Ego adalah Komponen terakhir untuk mengembangkan kepribadian adalah superego. Super ego adalah aspek kepribadian yang menampung semua standar internalisasi moral dan cita-cita yang kita peroleh dari kedua orang tua dan masyarakat.

\section{Tugas Seorang Konselor dalam Perkembangan Kepribadian Siswa}

Asar pemikiran penyelenggaran bimbingan dan konseling di sekolah, bukan semata-mata terletak pada ada atau tidak adanya landasan hukum (perundangundangan) atau ketentuan dari atas, namun yang lebih penting adalah menyangkut upaya memfasilitasi peserta didik yang selanjutnya di sebut konseli, agar mampu mengembangkan potensi dirinya atau mencapai tugas-tugas perkembanganya ( menyangkut aspek fisik, emosi, intelektual, sosial, dan moral-spritual).

Konseli sebagai seorang individu yang sedang berada dalam proses berkembang atau menjadi (on becoming), yaitu berkembang ke arah kematangan atau kemandirian. Untuk mencapai kematangam tersebut, konseli memerlukan bimbingan karena mereka masih kurang memiliki pemahaman atau wawasan tentang dirinya dan lingkunganya, juga pengalaman dalam menentukan arah kehidupannya. Disamping itu terdapat suatu keniscyaan bahwa proses perkembangan konseli tidak selalu berlangsung secara mulus, atau bebas dari masalah. Dengan kata lain, proses perkembangan itu tidak selalu berjalan dengan alur linier, lurus atau searah dengan potensi, harapan nilai-nilai yang di anut.
Perkembangan konseli tidak lepas dari pengaruh lingkungan, baik fisik, psikis maupun sosial. Sifat yang melekatpada lingkungan adalah perubahan. Perubahan yang terjadi dalam lingkungan dapat mempengaruhi gaya hidup (life style) warga masyarakat. Apabila perubahan yang terjadi itu sulit di prediksi, atau di luar jangkkauan kemampuan, maka akan melahirkan kesenjangan perilaku konseli, seperti terjadinya stagnasi ( Keadaan Terhenti atau Tidak aktif) dalam perkembangan, masalah-masalah peribadi atau penyimpangan prilaku.Perubahan lingkungan yang diduga mempengaruhi gaya hidup dan kesenjangan perkembangan tersebut diantaranya, pertumbuhan penduduk yang cerpat, pertumbuhan kotakota, kesenjangan ekonomi masyarakat, revolusi teknologi informasi,pergesaran fungsi atau struktur keluarga, dan perubahan struktur masyarakat serta perubahan struktur masyarakat dari agraris ke industri.

Penampilan perilaku remaja seperti di atas sangat tidak di harapkan karena tidak sesuai dengan sosok pribadi manusia Indonesia yang di cita-citakan, seperti tercantum dalam tujuan pendidikan nasional (UU No. 20 Tahun 2003), yaitu : (1) beriman dan bertaqwa terhadap Tuhan Yang Maha Esa, (2) berakhlak mulia , (3) memiliki pengetahuan dan ketrampilan, (4) memiliki kesehatan jasmani dan rohani, (5) memiliki kepribadian yang mantap dan mandiri, serta (6) memiliki rasa tanggung jawab kemasyarakat dan kebangsaan. Tujuan tersebut mempunyai implikasi imperatif (yang mengharuskan) bagi semua tingkat satuan pendidikan untuk senantiasa memantapkan proses pendidikannya secara bermutu ke arah pencapaian tujuan pendidikan tersebut. 
Upaya penangkal dan pencegah perilaku-perilaku yang tidak di harapkan seperti di sebutkan, adalah mengembangkan potensi konseli dan memfasilitasi mereka secara sistematik dan terprogram untuk mencapai standar kompetensi kemandirian. Upaya ini merupakan wilayah garapan bimbingan dan konseling yang harus di lakukan secara proaktif dan berbasis data tentang perkembangan konseli beserta sebagai faktor yang mempengaruhinya. Dengan demikian, pendidikan yang bermutu, efektif atau ideal adalah yang mengintegrasiskan tiga bidang kegiatan utamanya secara sinergi, yaitu bidang administratif dan kepemimpinan, bidang instruksional atau kurikulum, dan bidang bimbingan dan konseling, tetapi kurang memiliki kemampuan dan kematangan dalam aspek pribadi.

Pada saat ini telah terjadi perubahan paradigma pendekatan bimbingan dan konseling, yaitu dari pendekatan yang berorientasi tradisional, klinis dan terpusat pada konselor, kepada pendekatan yang berorintasi perkembangan dan preventif. Pelayanan bimbingan dan konseling komprehensif didasarkan kepada upaya pencapaian tugas perkembangan, pengembangan kompetensi, dan pengentasan masalah-masalah konseli. Tugas-tugas perkembangan dirumuskan sebagai standar kompetensi yang harus dicapai konseli, sehingga pendekatan ini di sebut juga bimbingan dan konseling berbasis standar (stanard based guidance and counseling).Standar dimaksud adalah standar kompetensi kemandirian serta pengembangan pribadi.

Konselor yang mempunyai tugas, tanggung jawab, wewenang dan hak secara penuh dalam kegiatan Bimbingan dan
Konseling terhadap sejumlah peserta didik. Pelayanan Bimbingan dan Konseling di sekolah merupakan kegiatan untuk membantu siswa dalam upaya mengembangkan peribadinya, penyesuaian terhadap lingkungan serta dapat merencanakan masa depan. Prayitno (2004:3) menyebutkan bahwa pada hakikatnya pelaksanaan Bimbingan dan Konseling di sekolah untuk pencapai tri sukses, yaitu: sukses bidang akademik, sukses dalam persiapan pribadi yang matang dan sukses dalam hubungan kemasyarakatan.

Dalam Pasal 39 Ayat 2 Undangundang Nomor 20 tahun 2003 tentang sistem Pendidikan Nasional mentebutkan:Pendidikan merupakan tenaga profesional tenaga profesional yang bertugas merencanakan dan melaksanakan proses pembelajaran, menilai hasil pembelajaran, melakukan pembimbingan dan pelatihan serta melakukan penelitian dan pengabdian kepada masyarakat, terutama pada pendidik pada perguruan tinggi.

Berdasarkan uraian diatas dapat dipahami bahwa seseorang konselor juga merupakan pendidik, yaitu tenaga profesional yang bertugas: (1) merencanakan dan menyelenggarakan proses pembelajaran, menilai hasil pembelajaran (3) melakukan pembimbingan dan pelatihan. Arah pelaksanan pembelajaran dan penilaian hasil pembelajaran yang di maksud adalah melaksanakan pelayanan bimbingan dan konseling yaitu berbagai keterkaitanya serta penilaianya.Semua pendidik, termasuk di dalamnya konselor, melakukan kegiatan pembelajaran, penilaian, pembimbingan dan pelatihan dengan berbagai muatan dalam ranah belajar kognitif, afektif, 
psikomotor , serta keimanan dan ketakwaan kepada Tuhan Yang Maha Esa.

\section{Metode}

Metode penelitian yang peneliti gunakan adalah metode survei yaitu penelitian dilakukan dengan terjun langsung ke lapangan mengambil data yang terjadi pada saat penelitian dilakukan dan mengadakan pengolahan data (kuantitatif). Menurut Arikunto, S. (2006: 34) Penelitian deskiptif kuantitatif merupakan data yang diperoleh berupa angka-angka yang selanjutnya dijabarkan ke dalam bentuk kalimat. Sedangkan Menurut Hadi, S. (2004), tipe desain penelitian yang digunakan adalah tipe penelitian eksperimental dengan memberikan perlakuan secara alami atau apa adanya. Peneliti meneliti pengaruh variabel peranan Guru BK secara simultan dalam mengembangkan kepribadian siswa kelas X SMK Presiden Kota Cirebon.

\section{Hasil dan Pembahasan}

Penelitian ini menggunakan koesioner siswa Kelas X SMK Presiden Kota Cirebon. Jumlah responden yang dijadikan sumber data sebanyak 39 siswa, yang terdiri dari 39 siswa Kelas X SMK Presiden Kota Cirebon. Data yang diperoleh dari hasil instrument peranan guru bimbingan dan konseling dalam mengembangkan kepribadian siswa Kelas X SMK Presiden Kota Cirebon.

\section{Statistik Deskriptif}

Statistik deskriptif atau analisa deskriptif adalah merupakan bentuk analisa data penelitian pada keseluruhan variabel untuk menjelaskan berbagai karateristik data yang mencakup nilai minimum, maksimum, rata-rata, dan standar deviasinya, frekuensi data dan histogram dari masing-masing variabel seperti yang ada pada tabel di bawah ini.

Tabel 1

Hasil Statistik Deskriptif

Descriptives

Descriptive Statistics

\begin{tabular}{|c|c|c|c|c|c|c|}
\hline & $\mathrm{N}$ & $\begin{array}{c}\text { Min } \\
\text { imum }\end{array}$ & $\begin{array}{l}\text { Maxi } \\
\text { mum }\end{array}$ & Mean & $\begin{array}{c}\text { Std. } \\
\text { Deviation }\end{array}$ & Variance \\
\hline $\begin{array}{l}\text { Bimbingan } \\
\text { Konseling }\end{array}$ & 22 & 79 & 117 & 90,64 & 7,774 & 60,433 \\
\hline $\begin{array}{l}\text { Kepribadian } \\
\text { Siswa }\end{array}$ & 22 & 81 & 99 & 90,09 & 4,352 & 18,944 \\
\hline $\begin{array}{c}\text { Valid } \\
\text { (listwise) }\end{array}$ & 22 & & & & & \\
\hline
\end{tabular}

Sumber: data primer yang diolah 2019

Berdasarkan tabel diatas dideskripsikan bahwa jumlah responden $(\mathrm{N})$ ada 22. Dari 22 responden ini variabel independen bimbingan dan konseling memiliki nilai minimum 79 dan maksimum 117 dengan rata-rata total jumlah 90,64 dan standar deviasinya 7,774. Pada variabel dependen kepribadian siswa minimum 81 dan maksimum 99 dengan rata-rata total jawaban 90,09 dan standar deviasinya 4,352 .

Tabel 2

Frekuensi Tabel Bimbingan dan Konseling

\begin{tabular}{|c|c|c|c|c|c|}
\hline \multicolumn{6}{|c|}{ Bimbingan dan Konseling } \\
\hline & & $\begin{array}{c}\text { Freque } \\
\text { ncy }\end{array}$ & $\begin{array}{l}\text { Perc } \\
\text { ent }\end{array}$ & $\begin{array}{c}\text { Valid } \\
\text { Percent }\end{array}$ & $\begin{array}{l}\text { Cumul } \\
\text { ative } \\
\text { Percent }\end{array}$ \\
\hline Valid & 79 & 1 & 4,5 & 4,5 & 4,5 \\
\hline & 80 & 1 & 4,5 & 4,5 & 9,1 \\
\hline & 83 & 1 & 4,5 & 4,5 & 13,6 \\
\hline & 84 & 1 & 4,5 & 4,5 & 18,2 \\
\hline & 85 & 1 & 4,5 & 4,5 & 22,7 \\
\hline & 87 & 3 & 13,6 & 13,6 & 36,4 \\
\hline & 88 & 1 & 4,5 & 4,5 & 40,9 \\
\hline & 90 & 1 & 4,5 & 4,5 & 45,5 \\
\hline & 91 & 2 & 9,1 & 9,1 & 54,5 \\
\hline & 92 & 3 & 13,6 & 13,6 & 68,2 \\
\hline & 93 & 3 & 13,6 & 13,6 & 81,8 \\
\hline
\end{tabular}




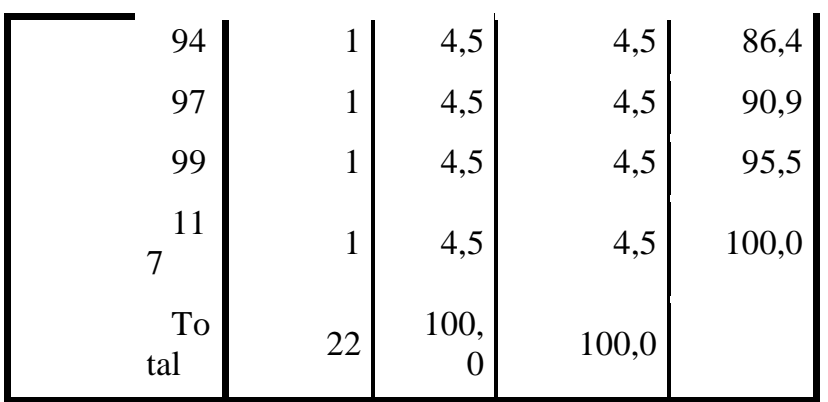

Sumber : Data Primer yang diolah 2019

Berdasarkan pada tabel diatas Bimbingan dan Konseling, Peranan Guru bimbingan dan konseling mempunyai nilai 87 terdapat 3 orang atau $(3 / 10 \times 100 \%)=$ $30 \%$ dan seterusnya.

Tabel 3

Frekuensi Tabel Kepribadian Siswa

Kepribadian Siswa

\begin{tabular}{|c|c|c|c|c|}
\hline & $\begin{array}{l}\text { Freque } \\
\text { ncy }\end{array}$ & $\begin{array}{l}\text { Perc } \\
\text { ent }\end{array}$ & $\begin{array}{r}\text { Valid } \\
\text { Percent }\end{array}$ & $\begin{array}{l}\text { Cumulat } \\
\text { ive } \\
\text { Percent }\end{array}$ \\
\hline Valid $\quad 81$ & 1 & 4,5 & 4,5 & 4,5 \\
\hline 83 & 1 & 4,5 & 4,5 & 9,1 \\
\hline 85 & 1 & 4,5 & 4,5 & 13,6 \\
\hline 86 & 1 & 4,5 & 4,5 & 18,2 \\
\hline 87 & 2 & 9,1 & 9,1 & 27,3 \\
\hline 88 & 1 & 4,5 & 4,5 & 31,8 \\
\hline 89 & 4 & 18,2 & 18,2 & 50,0 \\
\hline 91 & 2 & 9,1 & 9,1 & 59,1 \\
\hline 92 & 3 & 13,6 & 13,6 & 72,7 \\
\hline 93 & 1 & 4,5 & 4,5 & 77,3 \\
\hline 94 & 3 & 13,6 & 13,6 & 90,9 \\
\hline 97 & 1 & 4,5 & 4,5 & 95,5 \\
\hline 99 & 1 & 4,5 & 4,5 & 100,0 \\
\hline$\underset{\text { tal }}{\mathrm{To}}$ & 22 & $\begin{array}{r}100 \\
0\end{array}$ & 100,0 & \\
\hline
\end{tabular}

Sumber: Data Primer yang diolah 2016

Berdasarkan tabel diatas Prestasi Belajar Siswa, yang mempunyai Nilai Prestasi 94 terdapat 3 orang atau (3/10 x $100 \%)=30 \%$ dan seterusnya.

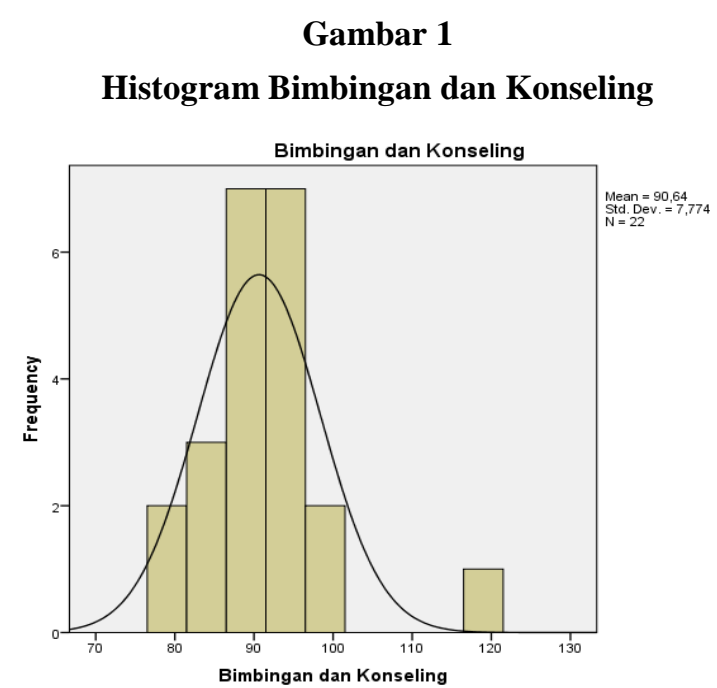

Sumber: Data Primer yang diolah 2019

Berdasarkan gambar diatas batang histogram Bimbingan dan Konseing terdiri dari garis Horizontal (X) berisi nilai Bimbingan dan Konseling dan garis Vertikal (Y) berisi frekuensi Bimbingan dan Konseling.

Gambar 2

Normal P-P Plot of Regression Standardized Residual

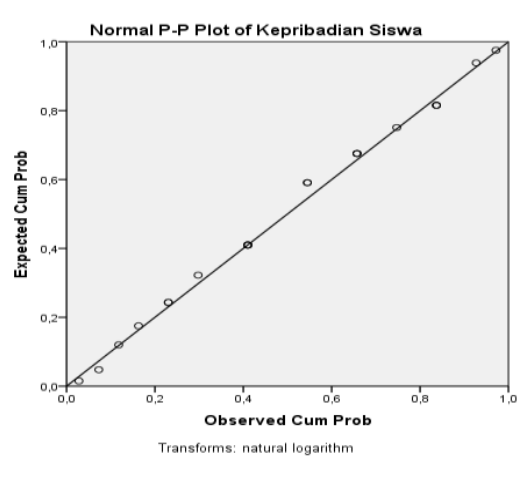


Gambar 3

Hasil Uji Normalitas

Normal P-Plot of Regression Standarized Residual

Independen Variabel : Bimbingan dan Konseling

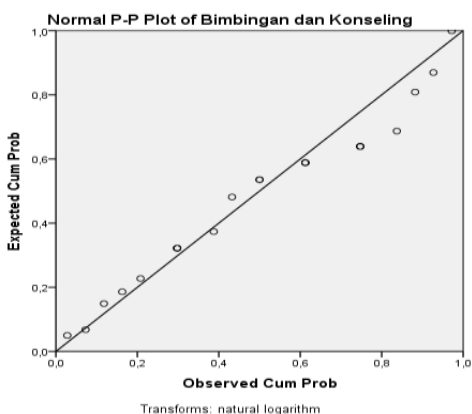

Gambar di atas menunjukkan bahwa semua data variabel independen Bimbingan dan Konseling adalah normal, karena titiktitik data tersebar di sekitar garis diagonal dan mengikuti garis diagonal. Gambar 3 di atas menunjukan hasil pengujian heteroskedastisitas.

\section{Kesimpulan}

Berdasarkan hasil pembahasan masalah mengenai peranan guru bimbingan konseling dengan pengembangan kepribadian siswa kelas X SMK Presiden Kota Cirebon, dapat disimpulkan sebagai berikut:

a. Bimbingan konseling kepada siswa kelas $X$ SMK Presiden Kota Cirebon dilaksanakan dengan baik dan penuh tanggungjawab, sehingga memperoleh nilai rata-rata sebesar 42,20. Nilai berarti bahwa pelaksanaan Bimbingan konseling dikategorikan sedang.

b. Pengembangan kepribadian siswa kelas X SMK Presiden Kota Cirebon dari hasil analisis data dan interpretasi bahwa pengembangan kepribadian siswa memperoleh nilai rata-rata 53,12 nilai ini berarti bahwa pengembangan kepribadian siswa dari hasil penelitian dikategorikan baik.

$$
\text { Berdasarkan hasil analisis }
$$
korelasional dari data penelitian bahwa terdapat hubungan Bimbingan konseling dengan pengembangan kepribadian siswa kelas X SMK Presiden Kota Cirebon. Hubungan ini ditunjukan dengan hasil analisis nilai dari koeffisien regresi sebesar 0,726 menyataakan bahwa hubungan kedua variabel ada pada rentang nilai diantara $0,60<r_{x y} \leq 0,80$, nilai korelasi tersebut dikategorikan tinggi. Artinya bahwa semakin baik dalam pelaksanaan layanan konseling individu, maka akan semakin baik nilai dari pengembangan kepribadian siswa.

\section{Daftar Pustaka}

Arikunto, S. 2006. Prosedur Penelitian Suatu Pendekatan Praktek (Edisi Revisi). Jakarta: Rineka Cipta.

Arikunto, Suharsimi. 2002. Prosedur Penelitian: Suatu Pendekatan Praktek. Rineka Cipta: Jakarta.

Bimo Walgito. 2004. Bimbingan dan Konseling di Sekolah. Yogyakarta: Pustaka Ilmu.

Departemen Agama RI, Al-Qur'an dan Tafsirnya, Jakarta: Lentera Abadi, 2010

Departemen Agama RI, Al-Qur'an dan Terjemahnya, Semarang: Toha Putra, 2012

Nurihsan, A. J. 2003. Dasar-dasar Bimbingan dan Konseling. Bandung: Mutiara

Prayitno, Erman Amti. 2004. Dasar-Dasar Bimbingan dan Konseling. Jakarta: Rineka Cipta. 
Rusmana, N. 2009. Bimbingan dan Konseling Kelompok di Sekolah (Metode, Teknik, dan Aplikasi). Bandung: Rizki Press.

Sukardi, Dewa Ketut. 2000. Pengantar Pelaksanaan Program Bimbingan Konseling di Sekolah, (Rineka Cipta: Jakarta

Sumandi Suryabrata. 2011. Sikap sebagai Motivasi diri dalam bekerja. Yogyakarta: Pustaka Ilmu.

Undang-undang No 22 Tahun 1999 dan Undang-undang No 25 Tahun 1999 tentang Otonomi Daerah

Undang-Undang No.20 Tahun 2003 tentang Sistem Pendidikan Nasional, Jakarta: Sinar Grafika, 2011

Winkel dan Sri Hastuti, 2008, Bimbingan dan konseling kelompok. Jakarta: Rineka Cipta

Baharuddin, 2007. Psikologi Perkembangan. Jakarta: Rineka Cipta

Muhammad Alim. 2006. Psikologi Belajar. Yogyakarta: Pustaka Ilmu.

Akyas Azhari. 2004. Psikologi Kepribadian. Bandung: Rizki Press 